\title{
Ser e fazer diferente... É possível provocar o desejo?
}

\author{
Being different and doing differently... Is it possible to incite desire?
}

\author{
Ser y hacer diferente... Es posible provocar el deseo $i$
}

\author{
Izabel Cristina Rios ${ }^{1}$
}

No artigo "Relação médico-paciente: desafios para a formação de profissionais da saúde", o autor apresenta a relação clínica como um procedimento médico com características próprias que, no seu processo de ensino, amplia o alcance do saber e da atuação no campo da subjetividade, seja porque incorpora aportes teóricos provenientes de outros campos do conhecimento, seja porque determina um outro modo de envolvimento do médico com o seu trabalho.

Como qualquer procedimento médico, no aspecto técnico, a relação clínica comporta uma dimensão teórica que se sustenta no corpo conceitual que fundamenta e explica o ato clínico, e uma dimensão prática que desenvolve métodos e instrumentos para a sua realização. Vai-se o tempo em que se acreditava que a relação médico-paciente era a expressão espontânea da arte médica, como aquela parte da medicina que não é ciência, que deriva da vocação, da bagagem cultural, do sexto sentido, da aura que envolve o médico e seu paciente em ato. Sem menosprezar esse universo intimista da vivência profissional, o que se busca aqui é a formação de uma competência relacional que passa, necessariamente, pela aquisição de conhecimentos sobre o modo como se fundamenta e opera a comunicação humana e a construção de vínculos, o desenvolvimento de habilidades interativas, e as atitudes sustentadas pela reflexão ética (Schraiber, 1997a; Habermas, 1989). No ensino de humanidades para alunos de medicina, temos nos defrontado com as mesmas dificuldades que o autor aponta: a necessidade de desenvolver professores para o ensino nessa área e a criação de metodologias adequadas para a produção de sentido para o aluno (sem o qual ele pode até decorar o texto, mas não vai legitimá-lo no seu agir).

Só nesse trecho já teríamos um grande desafio para a educação médica, mas o autor vai mais longe e, aos poucos, entra em terreno mais escorregadio... Não menos instigante.

${ }^{1}$ Médica; doutoranda; curso de Pós-Graduação em Medicina Preventiva; pesquisadora, Centro de Desenvolvimento de Educação Médica "Prof. Eduardo Marcondes", Faculdade de Medicina, Universidade de São Paulo (FMUSP). São Paulo, SP. <izarios@usp.br> 
Ao propor que se reconheça não só a singularidade de cada personagem em cena médico e paciente - mas, também, do momento único daquele encontro, posto que cada momento histórico vivido não mais se reproduz, assim como os acontecimentos que nele se contemplam (acontecimentos que podem ser fundamentais para os resultados que se buscam na relação clínica), o autor traz à tona uma questão ainda sem resposta: como promover mudanças tão profundas no fazer clínico de uma medicina cristalizada no modelo biomédico?

Atualmente, o campo da subjetividade na saúde encontra reconhecimento oficial no discurso da Política Nacional de Humanização, que coloca pacientes e profissionais, como sujeitos da ação, no centro das práticas de saúde (HumanizaSUS, 2004). A integralidade traz essa visão em maior aumento, e tecnologias leves para promover o cuidar da saúde estão sendo desenvolvidas no bojo do que, no nosso contexto, se chama humanização (Ayres, 2004). Entretanto, esse movimento técnico e político só timidamente alcançou a academia. A humanização não surgiu no âmago da medicina, na sua falência no cuidar, ou das queixas dos pacientes (é bom lembrar que o clamor público é por biomedicina para todos!). A humanização emergiu do interior das instituições de saúde, como resposta à violência institucional, e não é à toa que, na sua versão política, elegeu como alvos de intervenção a gestão e os processos de trabalho (HumanizaSUS, 2004; Reis, 2004).

A maioria dos médicos não se reconhece no discurso da humanização, porque, no modelo em que foi formado, o que falta para o bom atendimento são insumos, equipamentos de última geração e menos filas de pacientes para atender. $E$ não basta lhes apontar outro caminho... É preciso que sintam a necessidade de repensar a prática, para que haja mudança de fato.

A esse respeito, quero trazer outra questão. No campo da subjetividade, o que move as pessoas são os desejos (Benoit, 1989). A dimensão humana do cuidar, no exercício da biomedicina, está eclipsada porque são outras as redes desejantes em jogo. O desejo de ser médico não se realiza no encontro clínico com o paciente, mas na legitimação do discurso médico entre os pares, sendo o paciente um meio, e não um fim - ao menos tal como se apresenta a situação na contemporaneidade...

É claro que, em um breve retorno à história, vamos encontrar, até meados da década de 1940, uma profissão em formação, com poucos recursos científicos, e os médicos tentando firmarem-se como práticos exclusivos da cura (científica) em medicina, o que certamente fez com que cuidassem muito mais dos resultados e subprodutos de sua intervenção ainda pouco precisa (resultados, por vezes, "indesejáveis", como os efeitos colaterais ou erros involuntários). A humanização, enquanto atenção voltada ao bem- estar do paciente, disponibilidade para com as demandas e vigília constante dos resultados da sua intervenção, foi praticamente uma exigência técnica e de grande interesse corporativo na institucionalização da profissão, ainda que, à época, pudesse também representar uma ética mais atenta ao outro (o paciente), já que estávamos em tempos um pouco menos cínicos (Schraiber, 1997b).

Desenvolver nos alunos o interesse por investir em si mesmos e no paciente, como citado pelo autor, requer, a meu ver, mudar não só o ensino, mas a própria face da medicina. Para isso, será preciso instigar outros movimentos desejantes no interior do discurso médico, que apontem para a necessidade de outro enquadre para o encontro clínico. Quando o alcance do trabalho médico transcender o já posto pela medicina moderna e ampliar seu horizonte para resultados bem mais vastos tanto para o paciente, quanto para o próprio médico, nesse momento, sim, surgirá a demanda que move o desejo de aprender um outro jeito de ser médico e de exercer a medicina. Um outro jeito de ser e fazer que possa compreender o "aqui e agora" do encontro clínico como o momento preciso e precioso para o agir humanamente técnico. Um outro jeito de ser e fazer que encontre, no campo intersubjetivo, o lugar de sucessivas reconstruções das identidades do paciente e do médico, no qual a pessoa de cada um é também parte do tratamento. 
O resultado será uma prática mais reflexiva, da qual ambos, médico e paciente, sairão acrescidos. Tal prática só terá sentido para os médicos e estudantes de medicina quando o objetivo do trabalho médico for além do atualmente proposto. Portanto, a pergunta que fica é: em uma realidade cheia de fraturas, como a dos tempos atuais, como provocar outra ordem de desejo nos alunos que faça brotar na alma o interesse por essa maneira mais inteira de ser médico?... Ou mesmo uma maneira mais inteira de ser?

\section{Referências}

AYRES, J.R.C.M. Cuidado e reconstrução das práticas de saúde. Interface - Comunic. Saúde, Educ., v.14, n.8, p.73-91, 2004.

BENOIT, P. Psicanálise e medicina. Rio de Janeiro: Jorge Zahar, 1989.

HABERMAS, J. Consciência moral e agir comunicativo. Rio de Janeiro: Tempo Brasileiro, 1989.

HUMANIZASUS: Política Nacional de Humanização do Ministério da Saúde. Brasília, 2004.

REIS, A.O.A.; MARAZINA, I.; GALLO, P.R. A humanização na saúde como instância libertadora. Saúde Soc., v.13, n.3, p.36-43, 2004.

SCHRAIBER, L.B. No encontro da técnica com a ética: o exercício de julgar e decidir no cotidiano do trabalho em Medicina. Interface - Comunic., Saúde, Educ., v.1, n.1, p.123-38, 1997.

. Medicina tecnológica e prática profissional contemporânea: novos desafios, outros dilemas.

1997. Tese (Livre-docência) - Faculdade de Medicina, Universidade de São Paulo, São Paulo. 